\title{
Laboratory and field measurements of enantiomeric monoterpene emissions as a function of chemotype, light and temperature
}

\author{
W. Song ${ }^{1}$, M. Staudt ${ }^{2}$, I. Bourgeois ${ }^{2}$, and J. Williams ${ }^{1}$ \\ ${ }^{1}$ Max Planck Institut für Chemie, Hahn Meitner Weg 1, 55128 Mainz, Germany \\ ${ }^{2}$ Centre d'Ecologie Fonctionnelle et Evolutive (UMR5175), 1919 Route de Mende, 34293 Montpellier CEDEX 5, France
}

Correspondence to: J. Williams (jonathan.williams@mpic.de)

Received: 13 September 2013 - Published in Biogeosciences Discuss.: 29 October 2013

Revised: 21 January 2014 - Accepted: 3 February 2014 - Published: 14 March 2014

\begin{abstract}
Plants emit significant amounts of monoterpenes into the earth's atmosphere, where they react rapidly to form a multitude of gas phase species and particles. Many monoterpenes exist in mirror-image forms or enantiomers. In this study the enantiomeric monoterpene profile for several representative plants (Quercus ilex L., Rosmarinus officinalis L., and Pinus halepensis Mill.) was investigated as a function of chemotype, light and temperature both in the laboratory and in the field. Analysis of enantiomeric monoterpenes from 19 Quercus ilex individuals from Southern France and Spain revealed four regiospecific chemotypes (genetically fixed emission patterns). In agreement with previous work, only Quercus ilex emissions increased strongly with light. However, for all three plant species no consistent enantiomeric variation was observed as a function of light, and the enantiomeric ratio of $\alpha$-pinene was found to vary by less than $20 \%$ from 100 and $1000 \mu \mathrm{mol} \mathrm{m}^{-2} \mathrm{~s}^{-1}$ PAR (photosynthetically active radiation). The rate of monoterpene emission increased with temperature from all three plant species, but little variation in the enantiomeric distribution of $\alpha$-pinene was observed with temperature. There was more enantiomeric variability between individuals of the same species than could be induced by either light or temperature. Field measurements of $\alpha$-pinene enantiomer mixing ratios in the air, taken at a Quercus ilex forest in Southern France, and several other previously reported field enantiomeric ratio diel cycle profiles are compared. All show smoothly varying diel cycles (some positive and some negative) even over changing wind directions. This is surprising in comparison with variations of enantiomeric emission patterns shown by individuals of the same species.
\end{abstract}

\section{Introduction}

Terrestrial vegetation is an important global source of reactive volatile organic compounds (VOCs) contributing circa $1 \mathrm{Pg}\left(1 \times 10^{15} \mathrm{~g}\right)$ of carbon annually (Guenther, 2002), approximately ten times more than the estimated sum of anthropogenic VOC emissions, including fossil fuel and biomass burning (Piccot et al., 1992). Some of these VOCs may serve to attract pollinators, fruit dispersers and parasitoids of herbivores or as well as to repel herbivores, warn neighbouring plants of imminent herbivore and pathogen attack (Baldwin et al., 2006; Degenhardt and Gershenzon, 2000; Gershenzon and Dudareva, 2007; Hopke et al., 1994; van Dam et al., 2010). Moreover, some BVOCs have been shown to provide protection from environmental stresses such as ozone and high temperatures (Sharkey and Singsaas, 1995; Loreto and Velikova, 2001). BVOCs (biogenic VOCs) are produced in various plant tissues and compartments above- and belowground as the result of many biochemical pathways. Different plant families emit different subsets of these VOCs and these emissions may vary in intensity in response to endogenous and exogenous factors such as time of day, temperature, light, age, etc. (Kesselmeier and Staudt, 1999).

Among BVOCs, isoprene (C5) and monoterpenes (C10), which are often more than $50 \%$ of the total global biogenic VOC emission (Guenther et al., 1995), deserve special attention because of their high volatility, reactivity in the atmosphere and their large fractional contribution. Generally, all isoprenoids are derived from isopentenyl diphosphate (IPP, C5) and its isomer dimethylallyl diphosphate (DMAPP, C5). These precursors are either synthesized by the plastidic 1 deoxy-D-xylulose-5-phosphate (DXP) pathway (also known 
as methylerythritol phosphate (MEP) pathway) in the case of isoprene and monoterpenes or in the cytosolic mevalonate pathway in the case of sesquiterpenes (Mahmoud and Croteau, 2002). Isoprene and monoterpenes represent a large part of the non-methane BVOC flux with global flux estimates between 454 and $601 \mathrm{TgCy}^{-1}$ and between 32 and $127 \mathrm{Tg} \mathrm{Cy}^{-1}$, respectively (Arneth et al., 2008). Although there are large uncertainties in the magnitude of emission rates of individual and total BVOCs, in general, isoprene and monoterpenes are thought to be the strongest biogenic emissions and are the most commonly measured compounds (Staudt and Lhoutellier, 2011). The main driving variables for the emission of BVOCs are photosynthetically active radiation (PAR) and temperature which form the basis of all emission models (Arneth et al., 2008; Guenther et al., 2006; Monson et al., 2012, and references therein). However, other environmental factors such as the effect of seasonality, the $\mathrm{CO}_{2}$ level, the ozone level, mechanical stress and drought also have been studied (Blanch et al., 2007; Curci et al., 2009; McKinney et al., 2011; Penuelas and Staudt, 2010; Staudt et al., 2000, 2002) and incorporated into emission models recently (Arneth et al., 2007; Arneth and Niinemets, 2010; Grote et al., 2010; Keenan et al., 2009). In the past decade, great efforts have been made to improve regional and global models which estimate the source strength of BVOCs and in particular of isoprenoids (Grote and Niinemets, 2008; Guenther et al., 2006; Niinemets et al., 2002; Schurgers et al., 2009; Zimmer et al., 2000). While there is a generally accepted empirical emission algorithm for isoprene, which has been established to be influenced by both temperature and light (Guenther et al., 1993, 2006), for monoterpenes the situation is more complex - with some monoterpene emitters responding to temperature, and others to both light and temperature (Fuentes et al., 2000). In some species of plants, monoterpenes are synthesized and stored in secretory organs, such as the resin ducts within the leaves of conifers or the glandular trichomes surrounding the leaves and the stems of many Lamiaceae (Grote and Niinemets, 2008). The emissions rely on vaporization and diffusion from these extensive storage pools. In this case the emission rate of the monoterpene to the atmosphere is observed to increase exponentially with increasing leaf temperature. In other species such as the Mediterranean oak (Quercus ilex), no significant storage pool exists and the monoterpene emission occurs (in similar fashion to isoprene) when light is present (Guenther et al., 1993; Loreto et al., 1996a; Staudt and Seufert, 1995). Typically, the monoterpene emission from these plants respond to light, following a rectangular hyperbola similar to that of photosynthesis, while its response to temperature resembles a double Arrhenius function, perhaps reflecting the activity of specific enzymes limiting the monoterpene biosynthesis (Fischbach et al., 2002; Staudt and Bertin, 1998). There is increasing evidence that de novo emission and emission from storages can occur within the same plants and simultaneously, each one significantly contributing to the total emission (e.g. Ghirardo et al., 2010). In that case the temperature and light responses of the emission is a combination of the de novo and storage pool emission. For example, emissions increase with increasing light but do not cease in darkness.

Numerous monoterpenes and sesquiterpenes occur in two enantiomeric forms, for example $\alpha$-pinene exists as (+)- $\alpha$ pinene and (-)- $\alpha$-pinene (see Fig. 1). Typically such enantiomeric pairs have been measured and modelled together as one substance in ambient atmospheric chemistry studies (e.g. Guenther et al., 1995, 2006; Grote and Niinemets, 2008) as both enantiomers react at the same rates with ozone and $\mathrm{OH}$. However, for the biosphere (insect and plants) the two enantiomers can be very different and distinct molecules that may elicit opposite responses in pollinators and predators alike (Rostelien et al., 2005; Tooker and Hanks, 2004). Furthermore, variation in the individual enantiomers in ambient air may have the potential to provide clues about variable monoterpene sources within the plant cover through their individual responses to stimuli, and thereby represents a means to better link current empirical models to internal plant processes. Over the past 10 years, as chiral chromatography columns (such as cyclodextrin) have become commercially available, more chirally resolved studies have begun to emerge, providing captivating new information. Pioneering works on tree and plant emissions have shown very distinct enantiomeric fingerprints in different tree species (Yassaa et al., 2000) and even different chemotypes within the same species (Yassaa and Williams, 2007). It has been shown that clear changes in enantiomeric ratios occur when trees are subjected to mechanical stress, allowing processes upwind to be deduced (Eerdekens et al., 2009; Yassaa and Williams, 2007). Regiospecific enantiomeric ratios have been reported from tropical and boreal forests (Williams et al., 2007), and enantiomeric signatures have been used to constrain aerosol formation from isoprene (Noziere et al., 2011). Possible heterogeneous enantiomeric enrichment mechanisms on aerosols (Ebben et al., 2011; Stokes et al., 2009) have been investigated and new enantiomerically resolved marine sources of monoterpenes (Yassaa et al., 2008) have provided exciting new information and questions for this emerging field.

In some plant species the two enantiomers may be produced via different enzymes (Phillips et al., 1999). The individual enantiomer can have different biological activities. It might be advantageous to the plant to be able to alter the enantiomeric ratios it emits in order to communicate, via the atmosphere, to predators, pollinators and neighbouring plants. Indeed, several biochemical studies have shown that monoterpene-producing enzymes (i.e. monoterpene synthases) are enantiomer specific (Martin et al., 2004). Multiple enzymes producing a similar blend of terpenes, but with distinct chirality, can co-exist in plants and may be subject to different environmental controls (Faldt et al., 2006). This implies the presence of more than one underlying mechanism in their production and this unresolved mechanistic complexity 


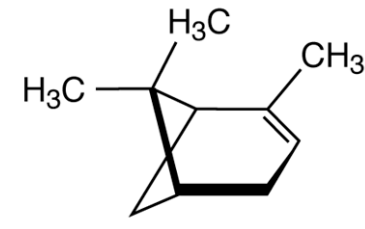

$(+)-\alpha$ - pinene

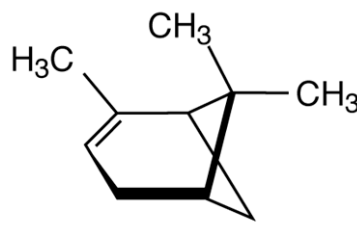

$(-)-\alpha$ - pinene

Fig. 1. Mirror image of $\alpha$-pinene enantiomers.

may help to explain the current difficulties encountered in establishing a reliable empirical monoterpene emission algorithm.

In this study, we screened the enantiomeric monoterpene fingerprints emitted by different holm oak individuals under standard conditions $\left(30^{\circ} \mathrm{C}\right.$ and 1000 PAR) in order to assess the extent of chemotype diversity in the species. Furthermore, we examined enantiomeric monoterpene emissions as a function of temperature and light under controlled laboratory conditions using three plant species that represent different types of monoterpene producers: Quercus ilex, an evergreen sclerophyllous oak, which is one of the most widespread tree species in the Mediterranean Basin and emits large amount of monoterpenes, was chosen as a representative emitter of non-stored monoterpenes whose emission is essentially controlled by the rate of biosynthesis. Further, we studied the conifer Pinus halepensis and the Lamiaceae Rosmarinus officinalis, two widespread monoterpenestoring species whose emissions are thought to mainly result from temperature-driven diffusion processes of the stored monoterpenes from storage organs independent of physiological processes. The enantiomeric response will be examined to find clues of different metabolic origins of monoterpenes and whether the two possible pools of monoterpenes synthesized in the plant can be differentiated (Loreto and Schnitzler, 2010), namely: (1) synthesis without storage in the chloroplasts of the green tissues; (2) synthesis in plastids of glandular organs (trichomes, resin ducts) with storage; (3) mixed type of (1) and (2). Thus, if no de novo emissions exist in the foliage of these plants, the effects of temperature on the gas vapour pressure in plant tissue and on the resistance along the emission pathway should be the dominant parameter of the emission rates. It is possible that in Pinus halepensis and Rosmarinus officinalis two pools exist, as has been demonstrated for Norway spruce and Scots pine (Ghirardo et al., 2010). If both de novo and storage emission types exist that produce exactly the same enantiomers, emissions should show no light dependence in enantiomeric ratio (i.e. there are emissions in the dark that increase with light but with the same enantiomeric pattern). If, however, the de novo and storage pool produce different enantiomers, the enantiomeric ratio in the emissions should change in response to both light and temperature. Furthermore, we report for comparison the diurnal profile of the enantiomeric

monoterpenes over different ecosystems. In particular, focus is set on $\alpha$-pinene whose enantiomeric ratios have been most commonly reported in field studies (Williams et al., 2007; Yassaa and Williams, 2005, 2007). The underlying question is whether enantiomeric signatures may be used to better understand the multitude of metabolic origins of monoterpenes that may exist in plants and to improve emission algorithms. For more accurate ecosystem response modelling, especially with regard to future climate changes, it will be necessary to link atmospheric chemistry models to ecological models including biological, mechanical and environmental stresses.

\section{Experiment}

\subsection{Plant material and the dynamic leaf enclosure cuvette set-up}

A total of 27 potted plants were studied at the CEFE-CNRS in Montpellier (France) during the months of April to July in 2009 and May to June in 2010, including the three nondeciduous trees, and shrubs Quercus ilex L., Rosmarinus officinalis L., and Pinus halepensis Mill.

Plants or seeds were collected from the field (Southern France and Spain) and were potted and grown outside at the institute. The individuals were $2-4$ years old and more than three individuals of each species were studied. In March, the plants were put in a greenhouse in Montpellier at an approximate day/night temperature of $25 / 15^{\circ} \mathrm{C}$ to initiate bud break.

A dynamic temperature and light-controlled chamber system (see Fig. 2) was used to determine VOC exchanges at the leaf level. The enclosure chamber (approximately $105 \mathrm{~mL}$ in volume) was constantly flushed with air at $500 \mathrm{~mL} \mathrm{~min}^{-1}$, resulting in an air exchange of the enclosure system on average every $5 \mathrm{~s}$. The in-flow air was first passed through a clean air generator (AIRMOPURE, Chromatotec, France) that purified and dried the ambient air. It was then re-humidified by passing a variable portion of the air stream through a waterfilled bottle. Homogenous mixing of the air in the enclosure was maintained by a Teflon fan at the bottom of the cuvette. Leaf and cuvette temperatures were monitored with two thermocouples (Chrom-Constantan, OMEGA). These two temperatures were rather close, with an average difference of $0.7^{\circ} \mathrm{C}$ during experiments. Cuvette and plants were illuminated with a white light source (OSRAM $1000 \mathrm{~W}$ ) filtered by a $5 \mathrm{~cm}$ water bath. PAR was measured with a quantum sensor (Licor, PAR-SB 190, Lincoln, NE, USA) located next to the chamber. All sampling lines that were made of Teflon were maintained at a constant temperature of $45^{\circ} \mathrm{C}$.

Before experiments, terminal shoots consisting of four to seven leaves were prepared for fixation in the cuvette by removing some leaves at the insertion point. This was done at least 1 week before the measurement to minimize disturbance effects. In order to ensure homogenous light repartition 


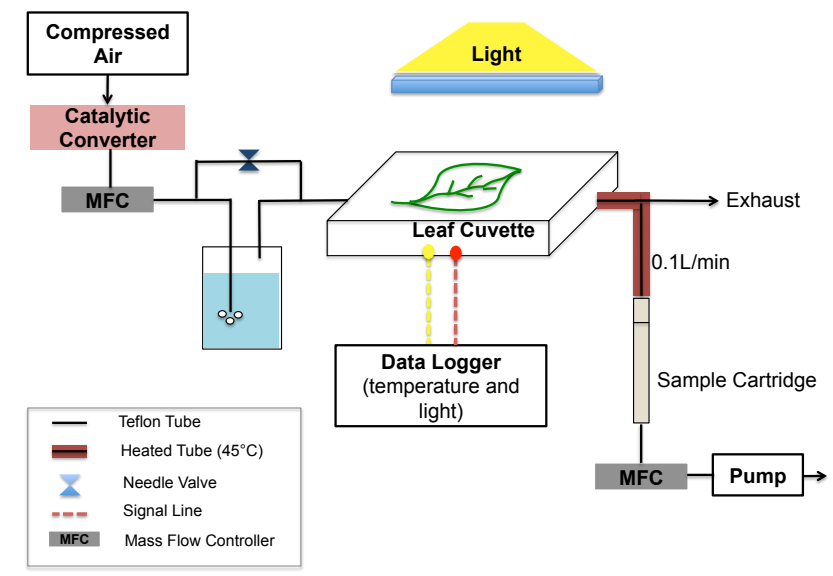

Fig. 2. A schematic of the dynamic leaf enclosure cuvette set-up.

on the adaxial surface of the leaves, several terminal leaves of an individual plant were placed horizontally to the light.

In order to ensure adaptation of the plants to the chamber environment, all measurement shoots of Quercus ilex were placed in the chamber at least $45 \mathrm{~min}$ prior to the measurements. Since the leaves of the conifer (Pinus halepensis) and the aromatic shrub (Rosmarinus officinalis) possess glands and ducts storing VOCs, mechanical stress can cause large bursts of VOCs from these plants (Niinemets et al., 2011). To avoid masking temperature- and light-driven effects by the stressed emission, these two species were enclosed at least $12 \mathrm{~h}$ before measurements began. To ensure that the enclosed leaves show normal physiological activity, photosynthesis and transpiration were measured (data not shown) by directing a constant portion of the inlet and outlet air through a $\mathrm{CO}_{2} / \mathrm{H}_{2} \mathrm{O}$ infrared gas analyzer (LI-COR Inc. 7000, Lincoln, Nebraska, USA).

First of all, as an assessment of chemotype variance within a given species, a total of 19 Quercus ilex individuals were measured for enantiomeric monoterpenes in steady state under standard conditions $\left(30^{\circ} \mathrm{C}\right.$ and $1000 \mu \mathrm{mol} \mathrm{m}^{-2} \mathrm{~s}^{-1}$ Photosynthetic Active Radiation (PAR)). To study light and temperature responses of emissions, the cuvette conditions were varied in terms of light $(0,100,200,400,800$ and $\left.1600 \mu \mathrm{mol} \mathrm{m}^{-2} \mathrm{~s}^{-1} \mathrm{PAR}\right)$ and temperature $(20,25,30,35$, $40,45^{\circ} \mathrm{C}$ ). The responses to light were determined by stepwise increases of 0 to approx. $1600 \mu \mathrm{mol} \mathrm{m}^{-2} \mathrm{~s}^{-1}$ PAR at a constant temperature of $30 \pm 0.2^{\circ} \mathrm{C}$. The responses to temperature were measured by increasing the enclosure temperature in $5^{\circ} \mathrm{C}$ increments from 20 to $45^{\circ} \mathrm{C}$ under 1000 PAR. At the end of each experiment, the studied leaves were harvested and leaf area and dry weight were determined. Projected leaf area was determined with an optical area meter (Delta-T Devices Ltd., Cambridge, UK), and leaf dry weights after drying at $60^{\circ} \mathrm{C}$ for at least $48 \mathrm{~h}$.

\subsection{Sampling and analysis}

Two types of adsorbent-filled cartridges (Carbograph I/II or Tenax and carbograph, MARKES) were used for this study. The cartridges were conditioned by purging with Helium 6.0 for $2 \mathrm{~h}$ at $350^{\circ} \mathrm{C}$ and $30 \mathrm{~min}$ at $380^{\circ} \mathrm{C}$ prior to use. Cuvette air was drawn at around $100 \mathrm{~mL} \mathrm{~min}^{-1}$ through the cartridges and the sample flow passed over the sorbent for $10 \mathrm{~min}$. Directly before analysis, cartridges were pre-purged for $5 \mathrm{~min}$ with Helium to reduce the water content and were then thermally desorbed by flushing the heated tubes at $200^{\circ} \mathrm{C}$ for $10 \mathrm{~min}$. The desorbed VOCs were trapped at $10^{\circ} \mathrm{C}$ on a low-dead-volume cold trap. The cold trap was $2 \mathrm{~mm}$ in diameter and filled by a $60 \mathrm{~mm}$-long bed of sorbent (Tenax TA and Carbograph I) supported by quartz wool. The cold trap was then heated to $200^{\circ} \mathrm{C}$ rapidly and then held there for $5 \mathrm{~min}$, while the sample was transferred to the GC column. In this work, a $\beta$-cyclodextrin column $(30 \mathrm{~m}, 0.256 \mathrm{~mm}$ I.D., $0.25 \mu \mathrm{m}$ film; J\&W Scientific, CA, USA) has been used for the separation of enantiomeric and non-enantiomeric monoterpenes, xylene isomers, and other VOCs. The column temperature was initially held for $5 \mathrm{~min}$ at $40^{\circ} \mathrm{C}$ and raised to $120^{\circ} \mathrm{C}$ at $1.5^{\circ} \mathrm{C} \mathrm{min}^{-1}$ then to $200^{\circ} \mathrm{C}$ at a rate of $30^{\circ} \mathrm{C} \min ^{-1}$.

The measurement systems were calibrated with either a pressurized gas standard mixture (National Physical Laboratory, UK) containing enantiomeric monoterpenes, or liquid standards which were prepared from pure authentic standards (Fluka, Aldrich, Bedoukan) dissolved in methanol. In the latter case, a microlitre-level liquid standard was injected into the cartridge and flushed with helium for $5 \mathrm{~min}$. Calibrations were performed every 8-10 samples. Multipoint calibrations for all reported species for both gas and liquid standards revealed a good linear dependency of peak area to the respective compound concentration $\left(r^{2}>0.9\right)$. Both data sets have been combined here. Empty cuvette air was measured each time before installing a new plant and this showed no significant levels of the compounds discussed. Table 1 shows the retention time, precision and overall uncertainty of the selected BVOCs which are the main focus of this work. The overall uncertainty was calculated based on the calibration standard (stated accuracy 5\%, National Physical Laboratory) and the precision of the chemical.

\section{Results and discussion}

\subsection{Monoterpene emission composition for Quercus ilex under standard conditions - an assessment of chemotype diversity}

Although BVOC emissions are strongly modulated by the biotic and abiotic environment, their compositional fingerprints have been used as chemotaxonomic markers in order to better understand the geographical distribution of certain species 
Table 1. Overview of the measured compounds.

\begin{tabular}{lrrr}
\hline Compounds & $\begin{array}{r}\text { Retention } \\
\text { time }(\min )\end{array}$ & $\begin{array}{r}\text { Precision } \\
(\%)\end{array}$ & $\begin{array}{r}\text { Uncertainty } \\
(\%)\end{array}$ \\
\hline Isoprene & 1.724 & 10 & 11.2 \\
$(-)-\alpha$-Pinene & 21.146 & 9.5 & 10.7 \\
$(+)-\alpha$-Pinene & 21.973 & 12.6 & 13.5 \\
Myrcene & 22.607 & 13.5 & 14.4 \\
$\Delta 3$-Carene & 25.404 & 17.7 & 18.4 \\
$(+)$ - $\beta$-Pinene & 25.851 & 16.6 & 17.3 \\
$(-)-\beta$-Pinene & 26.237 & 18 & 18.7 \\
Ocimene & 27.05 & 19.3 & 19.9 \\
$(-)$-Limonene & 27.472 & 18.6 & 19.2 \\
$p$-Cymene & 27.477 & 18.1 & 18.7 \\
$(+)-$ Limonene & 27.81 & 18.6 & 19.3 \\
Eucalyptol & 32.874 & 14.1 & 15 \\
$(-) /(+)-C a m p h o r ~$ & 49.39 & 33.5 & 33.9 \\
\hline
\end{tabular}

(Loreto et al., 2009). Quercus ilex emits large amounts of monoterpenes but small to non-detectable amounts of isoprene (Plaza et al., 2005; Staudt and Bertin, 1998). Previous studies have shown the compositional profile of the emissions is mainly genetically controlled (Staudt et al., 2001, 2003, 2004), but none of these have taken enantiomers into account. Figure 3 shows the percent composition of individual monoterpenes emitted from 19 Quercus ilex individuals that originated from two different areas (southern Spain and southwest France) at standard temperature $\left(30^{\circ} \mathrm{C}\right)$ and light (1000 PAR) conditions. These contrasting emissions strongly suggest the existence of distinct chemotypes (genetically fixed) within this tree species rather than environmentally induced emission differences. The results provide a limited assessment of the geographic differences in the BVOC emission profile and an overview of potential chemotypes prevalent in the region. A total of 11 chiral and nonchiral monoterpene hydrocarbons, including enantiomeric pairs of $\alpha$-pinene, $\beta$-pinene, camphene and limonene, have been identified in all samples. The main monoterpene compounds emitted were $\alpha$-pinene, $\beta$-pinene, limonene, myrcene and sabinene. As can be seen in Fig. 3, there are generally two types of emitter within this selection of Quercus ilex individuals: a limonene-dominated emitter (e.g. QS1) and a pinene-dominated emitter (e.g. QF1). Within the six individuals originating from Spain, both limonene- and pinenedominated individuals were identified. Thus, if we ignore for a moment the enantiomeric speciation, no clear regiospecific monoterpene emission pattern exists within the group studied here. For those individuals from Spain identified as a limonene-dominated emitter, $(-)$-limonene and $(+)-$ $\alpha$-pinene were the overwhelmingly dominant enantiomers. In contrast to the pinene chemotype, (-)- $\alpha$-pinene and $(+)$-limonene (with some $(-)-\beta$-pinene) are the predominant enantiomers. For those originally from France, almost all of the pinene-dominated chemotype showed a clear

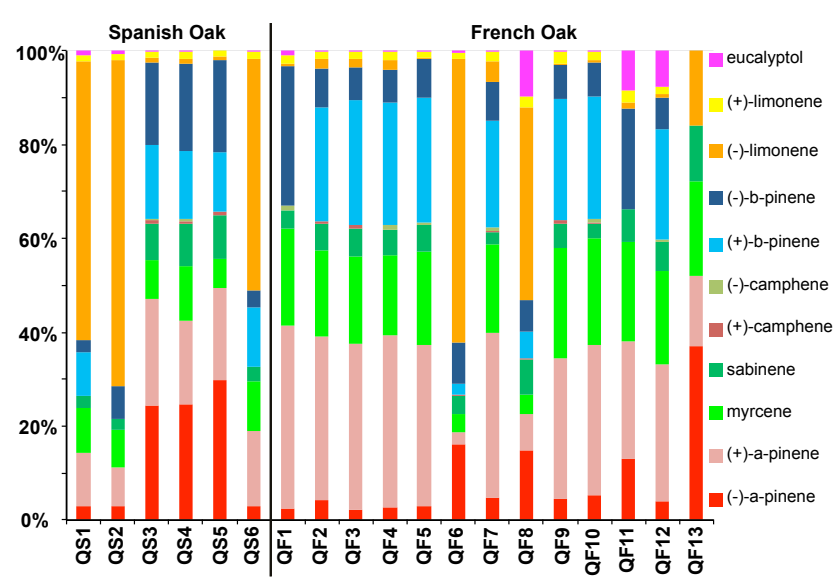

Fig. 3. Screening of Quercus ilex. L originally from different areas (southern Spain and France) at standard conditions.

$(+)$-enantiomer preference in the case of $\alpha$-pinene and (+)$\beta$-pinene preference. Only two individuals from France were found to be limonene emitters, and these showed an enantiomeric excess of the (-)-enantiomer for all of the three chiral monoterpenes, namely $\alpha$-pinene, $\beta$-pinene and limonene. Table 2 lists the chemotypes of studied individuals. As can be seen clearly, four distinct chemotypes can be ascertained if the enantiomeric speciation is taken into account: (I) high limonene with high (-)- $\alpha$-pinene (all were from France); (II) high limonene with high (+)- $\alpha$-pinene (all were from Spain); (III) high pinene with high (-)- $\alpha$-pinene (most were from Spain); (IV) high pinene with high (+)- $\alpha$-pinene (all were from France).

Therefore the enantiomeric signatures of monoterpenes from Quercus ilex originating from Spain and France appear to be distinctly different, at least for this sample set. This echoes the regiospecific enantiomeric differences noted between tropical and boreal forests (Williams et al., 2007; Yassaa et al., 2012) although on a much smaller geographical scale. Interestingly, it would not be possible to distinguish the French and Spanish individuals on the basis of nonenantiomerically resolved monoterpene emissions since both limonene- and pinene-dominated individuals exist in both groups. It is tempting to speculate whether the origin of a wood sample or individual plant may be attributed to Spain or France on the basis of the enantiomeric emissions (using Table 2), but the number of individuals sampled must be greatly increased to test this hypothesis. However, this initial screening experiment has served to demonstrate that multiple chemotypes exist within the tree species examined in this study.

\subsection{Light dependence}

As described in the previous section (Sect. 3.1), the emission rate of monoterpenes from Quercus ilex is controlled by light (Bertin et al., 1997; Staudt and Seufert, 1995; Staudt 
Table 2. Chemotypes of the screened individuals.

\begin{tabular}{llrl}
\hline Chemotype & Emission signature & Number of individuals & Origin \\
\hline I & Limonene_(-)- $\alpha$-pinene & 2 & France \\
II & Limonene_(+)- $\alpha$-pinene & 3 & Spain \\
III & Pinene_(-)- $\alpha$-pinene & 4 & $*$ Spain(3), France (1) \\
IV & Pinene_(+)- $\alpha$-pinene & 10 & France \\
\hline
\end{tabular}

* This chemotype group contains three species from Spain and one from France.

and Bertin, 1998). Therefore, monoterpene emission should immediately follow synthesis, as for isoprene which has been proven by isotopic labelling experiments (Loreto et al., 1996b). On the other hand, Pinus halepensis and Rosmarinus officinalis produce and store monoterpenes in secretory organs such as resin ducts (Bracho-Nunez et al., 2011; Kesselmeier and Staudt, 1999). Figure 4 shows the emission normalized by dividing by emission at $800 \mu \mathrm{mol} \mathrm{m}^{-2} \mathrm{~s}^{-1}$ PAR from these three different plant species and assumed two different emission types (de novo and stored), measured at six different levels of light using $\alpha$-pinene as an example. For Quercus ilex, a clear light-dependent emission profile is shown, with emission rates increasing with light. The dependence is strong, with emissions increasing tenfold between 100 and $1000 \mu \mathrm{mol} \mathrm{m}^{-2} \mathrm{~s}^{-1}$ PAR. The emissions from $\mathrm{Pi}$ nus halepensis were much lower in magnitude than those of Quercus ilex with a relatively small change with light. For Rosmarinus officinalis, the emission rates were likewise lower than that of Quercus ilex, from $0.8-1.5 \mu \mathrm{g} \mathrm{g}^{-1} \mathrm{~h}^{-1}$ for (+)- $\alpha$-pinene, and $0.2-0.3 \mu \mathrm{gg}^{-1} \mathrm{~h}^{-1}$ for (-)- $\alpha$-pinene. A rapid increase of emission at lower light intensity (from 0 to 100 PAR) and a much slower increase or decrease at higher light intensity was observed. However, it should be noted that emissions were still significant in darkness (note the different $y$ scales in Fig. 4) and the apparent slight increase of the emission rate with increasing light might be due to small unresolved leaf temperature increases during the lightdependence experiments. Pinene emissions from Rosmarinus officinalis appear to increase from 0 to 400 PAR (approximately doubling in rate) and decrease thereafter. The pinene enantiomers appear to show a similar dependency to light and no evidence for reversing of enantiomeric dominance was observed. The enantiomeric response to light for all three plant species is discussed below.

In this section we present the enantiomeric signature using the enantiomeric fraction of $(-)-\alpha$-pinene (i.e. (-)enantiomer $/((+)$-enantiomer $+(-)$-enantiomer $) \times 100)$.

Among the replicates as a function of light, there were clear differences in the emission of the enantiomers $((-)$ and (+)- $\alpha$-pinene between the samples). In the case of Quercus ilex (Fig. 5), four replicates - including two originally from Spain (QS2 and QS5) and two from France (QF7 and QF8); two limonene emitters (QS2 and QF7), and two pinene emitters (QS5 and QF8) were analysed for light

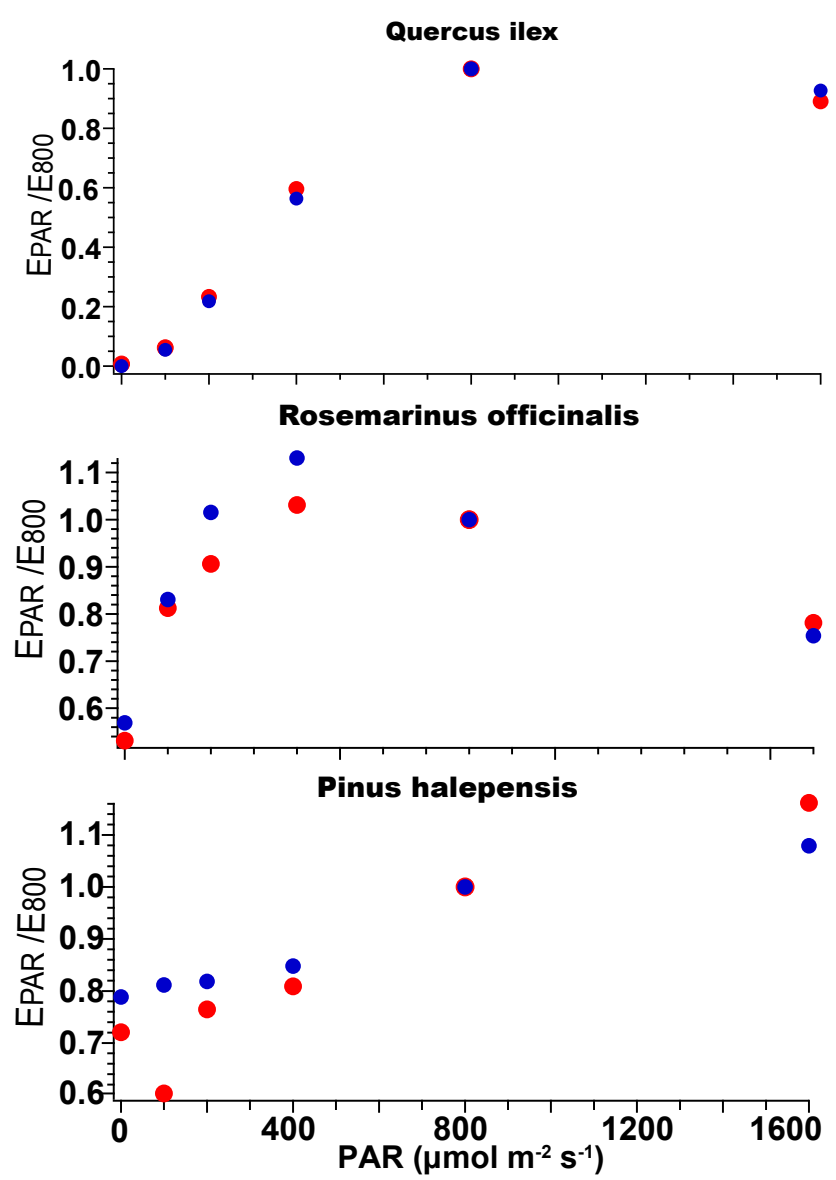

Fig. 4. An example of $(-) /(+)-\alpha$-pinene emission which was normalized by dividing by emission at $800 \mu \mathrm{mol} \mathrm{m}^{-2} \mathrm{~s}^{-1}$ from three selected plant species in dependency with light (at $30^{\circ} \mathrm{C}$ ). The red points represent normalized (-)- $\alpha$-pinene emissions and the blue points show the normalized (+)- $\alpha$-pinene emissions.

responses. The result without light is excluded due to the low emission rate detected in the darkness. Two individuals (QS2 and QF7), which are the limonene-dominated chemotype, showed a clear $(+)-\alpha$-pinene dominance with only $20-30 \%$ (-)- $\alpha$-pinene in the total $\alpha$-pinene emission; moreover, the ratio was generally stable with light. For one pinene chemotype (QS5), the (-)- $\alpha$-pinene was close to $50 \%$ (around 60-55\%) meaning no significant enantiomeric preference. The enantiomer emission ratio was quite stable 


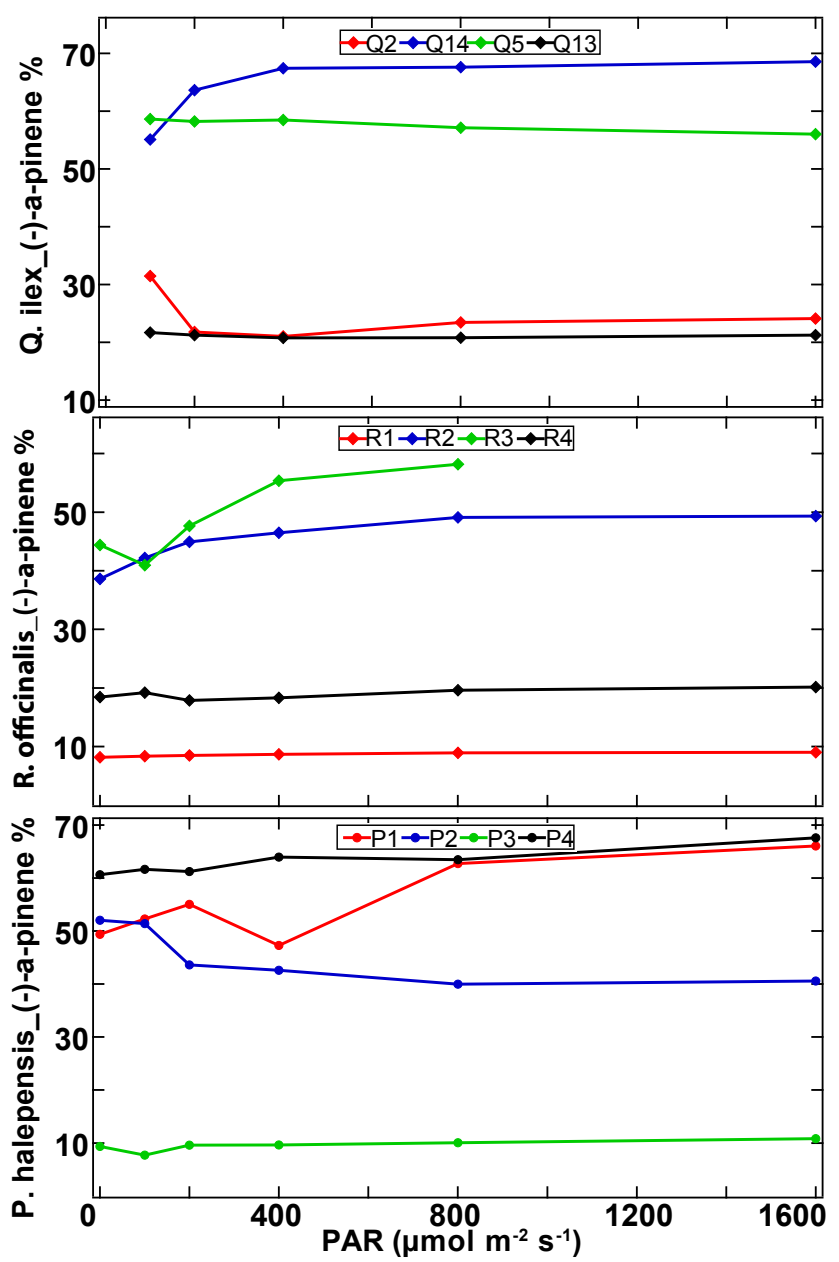

Fig. 5. Enantiomeric fraction of (-)- $\alpha$-pinene of Quercus ilex, Rosmarinus officinalis and Pinus halepensis as a function of light.

at low light intensity, but decreased slightly with increasing light levels. In contrast, the other pinene emitter, individual $\mathrm{QF} 8$, exhibited the reverse enantiomeric signature, namely that $(-)-\alpha$-pinene predominated in the emission and the (-)-enantiomer increased weakly with light, $10 \%$ between 100 and 400 PAR.

For Rosmarinus officinalis (Fig. 5), the emission was dominated by $(+)-\alpha$-pinene which is consistent with the only previous study (Yassaa and Williams, 2005). Individual R1 showed the strongest $(+)-\alpha$-pinene predominance, but exhibited little change with light (ca. $10 \%$ in $(-)-\alpha$-pinene emission ratio) Similarly, there was about $20 \%$ of $(-)-\alpha$-pinene in the emission of individual R4 which also had a relatively stable enantiomeric emission ratio. In contrast, the replicates $\mathrm{R} 2$ and R3 emitted much higher (-)- $\alpha$-pinene than individual R1 and R4, from 39 to $49 \%$ and from 41 to $58 \%$, respectively. These two replicates, with the higher fraction of $(-)-\alpha$-pinene showed a weak increase in $(-)-\alpha$-pinene emission $(5-20 \%)$ with light.
For Pinus halepensis (Fig. 5), individuals P1 and P2 had initially racemic $\alpha$-pinene emission ratios (50\% of $(-)-\alpha$ pinene) in the darkness. While P1 showed (-)-enantiomer increasing weakly (ca. 10\%) over the light range, P1 showed the reverse trend, again with a relatively weak change in emission ratio. Individual P3 emitted with strong $(+)-\alpha-$ pinene enantiomer predominance and again showed little change in the (-)-enantiomer emission (9-11\%) with light, and individual $\mathrm{P} 4$ showed an (-)-enantiomer preference $(60$ $67 \%$ ) with again little discernible change with light.

From Figs. 4 and 5 it is clear that significant differences exist between the mean enantiomeric emissions of individuals (in terms of $\alpha$-pinene). For Rosmarinus officinalis, in almost all cases the $(+)-\alpha$-pinene was shown to be predominant. For Quercus ilex and for Pinus halepensis there are individuals with (-)- $\alpha$-pinene- and (+)- $\alpha$-pinene-dominated emissions. This indicates that Pinus halepensis also has different chemotypes, as was shown to be the case for Quercus ilex in Sect. 3.1. In all cases the variation in enantiomeric emission ratio with light, when present at all, was weak (0$20 \%)$.

\subsection{Temperature dependence}

Measured emissions of monoterpenes responded to the temperature changes imposed (see examples for $\alpha$-pinene emissions normalized by dividing by emission at $30^{\circ} \mathrm{C}$ in Fig. 6). The highest emission rates $\left(5-25 \mu \mathrm{g} \mathrm{g}^{-1} \mathrm{~h}^{-1}\right)$ were found from Quercus ilex which increased until $40^{\circ} \mathrm{C}$, and then exhibited a sharp decrease at the highest temperature of $45^{\circ} \mathrm{C}$. In comparison, both of the emission rates of Pinus halepensis and Rosmarinus officinalis were very low, but a clear exponential increase with temperature, especially for a rapid increase of (-)- $\alpha$-pinene at higher temperatures, was observed.

In the following section the (-)- $\alpha$-pinene fraction is investigated as a function of temperature. Regarding Quercus ilex (Fig. 7), individuals QS2 and QF7, both limonene chemotype and strong $(+)-\alpha$-pinene enantiomer emitters (less than $30 \%$ of (-)-enantiomer in total $\alpha$-pinene emission) exhibited opposite albeit weak (0-15\%) enantiomeric trends in response to temperature: the (-)-enantiomer of individual QS2 was found to decrease (more (+)- $\alpha$-pinene enriched) at the highest temperatures $\left(40-45^{\circ} \mathrm{C}\right)$ while the individual QF7 showed an increased (-)- $\alpha$-pinene enrichment at the highest temperatures. For the pinene chemotype, the ratios of individual QS5 with weak (+)-enantiomeric preference showed no clear trend in ratio regarding temperature. The other pinene emitter (individual QF8) in which (-)enantiomer predominated in the emission, was found to remain stable until $35^{\circ} \mathrm{C}$ and then rapidly decreased at the highest points $\left(40-45^{\circ} \mathrm{C}\right)$.

Figure 7 shows the enantiomeric profile of Rosmarinus officinalis emissions. For replicates R1 and R4, there is a modest decrease in (-)- $\alpha$-pinene emission in response to temperature from 25 to $45^{\circ} \mathrm{C}$. Replicate $\mathrm{R} 2$ shows no clear 

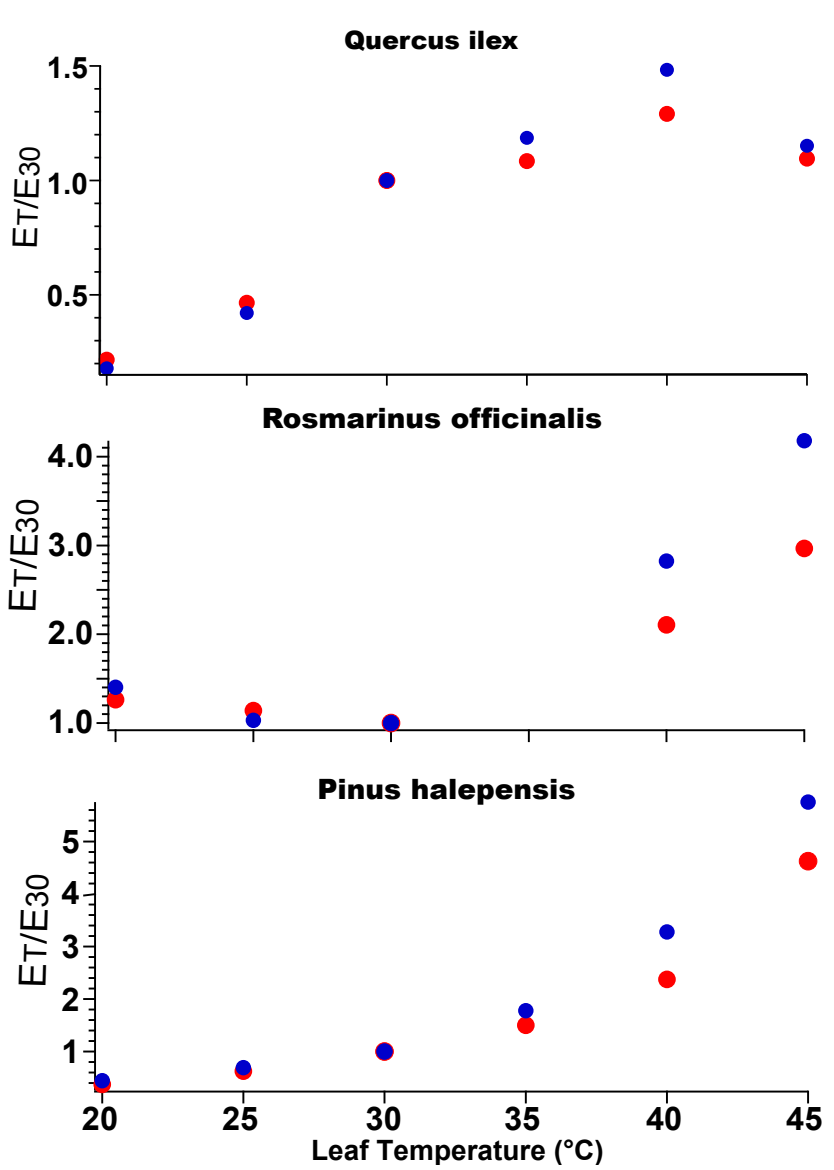

Fig. 6. An example of $(-) /(+)-\alpha$-pinene emission which was normalized by dividing by emission at $30^{\circ} \mathrm{C}$ from different plant species in dependency with temperature. The red points represent normalized (-)- $\alpha$-pinene emissions and the blue points show the normalized (+)- $\alpha$-pinene emissions.

dependence on temperature varying, between 44 and $50 \%$ of $(-)-\alpha$-pinene. Replicate R3 shows a weak increase in $(-)-\alpha-$ pinene with temperature. Thus the strongest impact on enantiomeric emission by temperature is shown for replicates R1 and R3.

In the case of Pinus halepensis (Fig. 7), replicate P1 shows the (-)-enantiomer emission increasing in response to temperatures between 20 and $30^{\circ} \mathrm{C}$ by about $10 \%$, but thereafter decreasing (becoming more (+)-enantiomer rich) at higher temperatures. Replicates $\mathrm{P} 2$ and $\mathrm{P} 3$ are strongly dominated by the (+)-enantiomer with less than $20 \%$ of (-)-enantiomer and show no clear dependence on temperatures. Replicate P4 shows the strongest (-)-enantiomer preference of all four replicates (the (-)- $\alpha$-pinene accounts for $60-80 \%$ of the total ( -$)-\alpha$-pinene) but decreases slightly with temperature which is consistent with its change as a function of light.

Regarding Pinus halepensis and Rosmarinus officinalis, the (-)-enantiomer fraction of those individuals that are predominant with (-)-enantiomer were found to either increase or decrease with temperature, and those with a preference
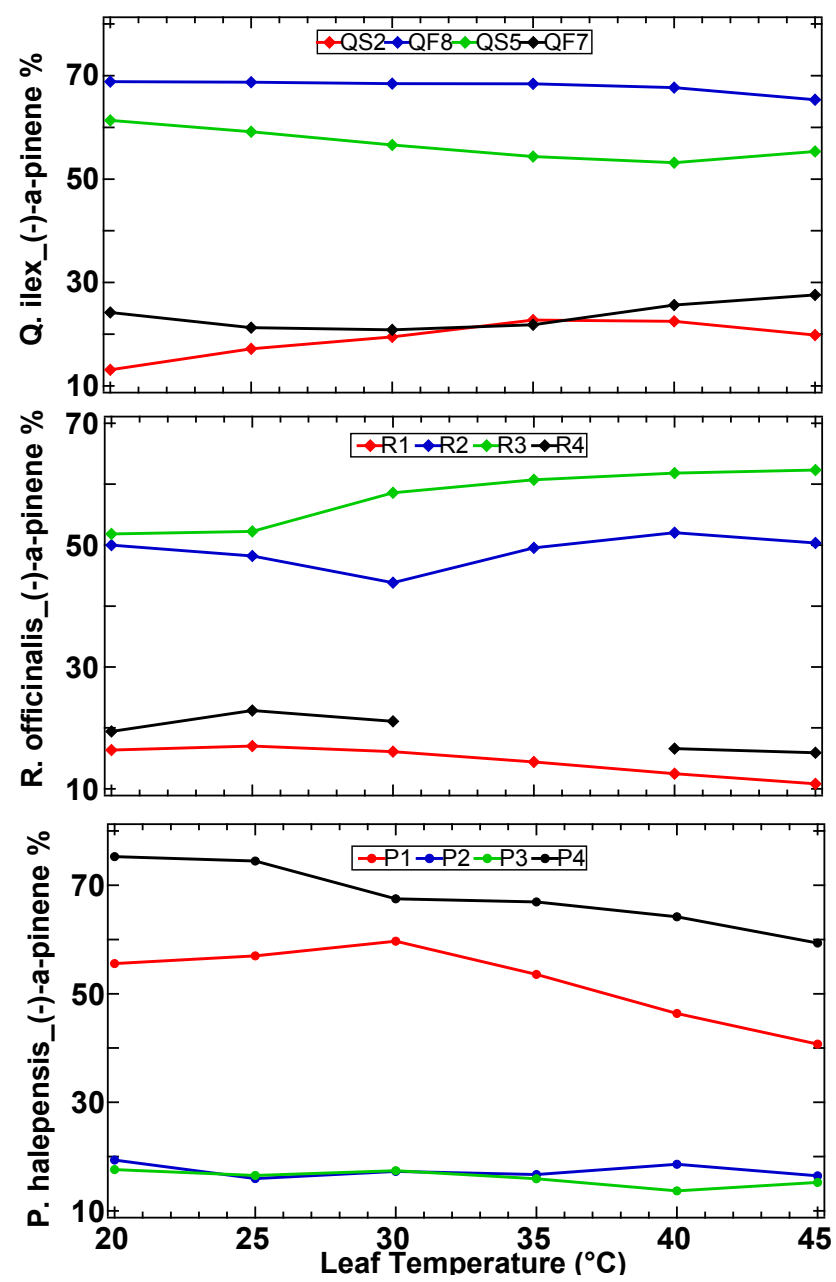

Fig. 7. Enantiomeric fraction of (-)- $\alpha$-pinene in the emission of Quercus ilex, Rosmarinus officinalis and Pinus halepensis as a function of temperature.

of (+)-enantiomer showed a relative stable (-)-enantiomer fraction with temperature. This is further evidence that different chemotypes of the same species have different enzymes, producing enantiomer-specific monoterpenes.

\subsection{Field measurements over different ecosystems}

Field measurements over different forest ecosystems (oak forest, boreal forest and temperate forest) will be discussed for comparison with the laboratory results in the following section. For all locations we examine the mixing ratios of $\alpha$ pinene in terms of absolute mixing ratio and $(-)-\alpha$-pinene fraction. The diel cycles of $\alpha$-pinene are shown in Fig. 8.

A single-day field measurement was performed over a Quercus ilex forest in Puéchabon, Southern France $\left(43^{\circ} 43^{\prime} \mathrm{N}, 3^{\circ} 37^{\prime} \mathrm{E}\right)$, June 2010 . The Puéchabon forest is a natural forest which was previously used to produce charcoal (coppice). The last cut was about 40 years ago. Therefore, each tree usually has several stems that result from a several 


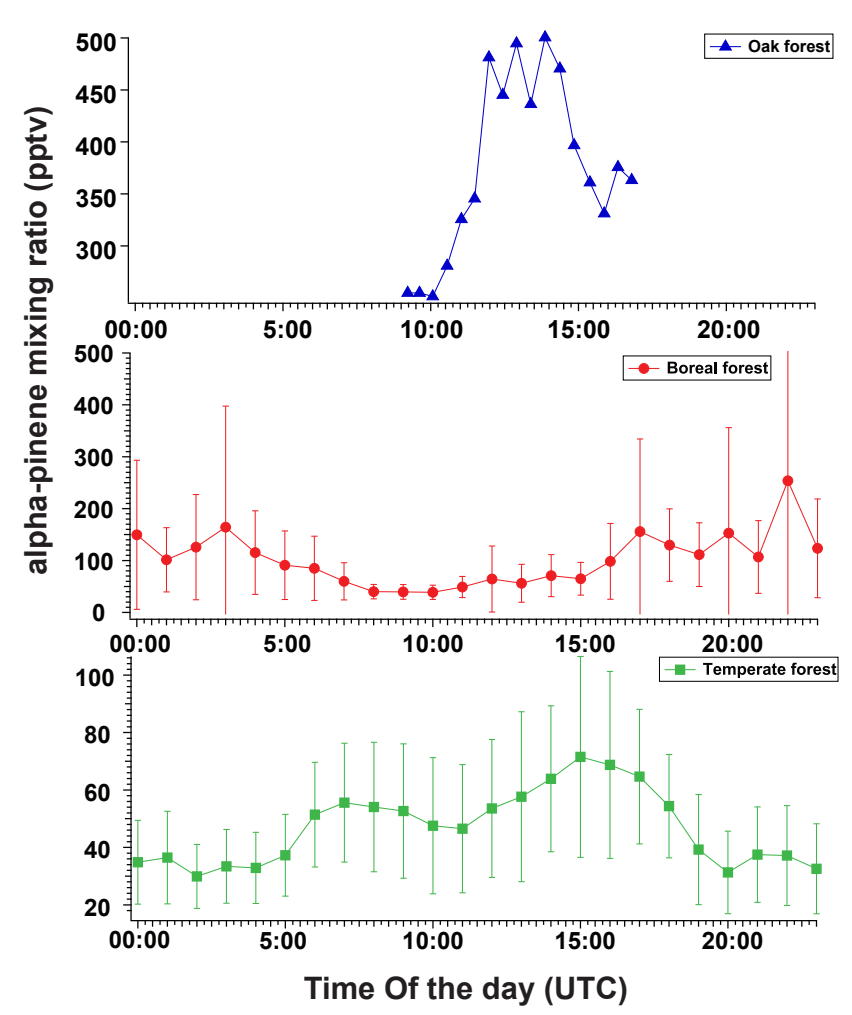

Fig. 8. Diel cycle of $\alpha$-pinene mixing ratios during the measurement period. For boreal forest and temperate forest measurements, the marks represent the mean value of every hour, the error bars were the standard deviation (boreal forest: $n>13$; temperate forest: $n>12$ ); for oak forest measurements, the solid triangle represents the mixing ratio observed.

hundred-year-old rootstock. Measurements were made during the daytime from 09:00 to 18:00 (local time) by drawing air through a cartridge in the same manner as for the laboratory experiments. The ambient temperature was from 16 to $21^{\circ} \mathrm{C}$. The temperature and light reached its maximum value at around 14:00 (local time). The sampling line was placed about $2 \mathrm{~m}$ above the canopy top.

The mixing ratios of $\alpha$-pinene increased clearly during the day over Puéchabon forest and peaked in the afternoon, from 14:00 to 15:00 local time (see Fig. 8, oak forest). However, for $\alpha$-pinene the $(-)$-enantiomer fraction had a clear decrease towards noon with the lowest value around 14:0015:00 (Fig. 9, oak forest). That is to say that the relative abundance of the (-)-enantiomer for $\alpha$-pinene decreased throughout the morning with increasing light and temperature levels, becoming $(+)$-enantiomer-dominated at noon. For limonene enantiomers, the $(-)$-limonene was always predominant by a factor of circa 10 . For $\beta$-pinene, the enantiomeric ratio varies but the $(+)$-enantiomer predominates over the forest throughout the day.

In general, the abundance of a particular monoterpene in ambient air is dependent on (1) the emission source strength from forest tree species, (2) the atmospheric removal rates

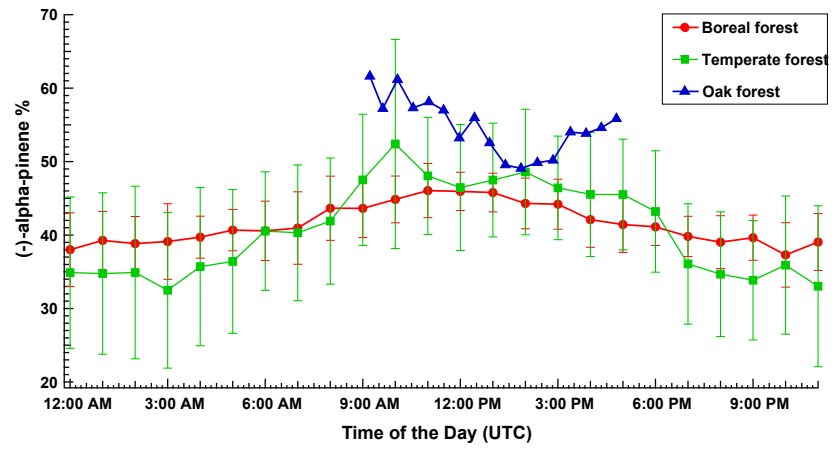

Fig. 9. Enantiomeric fraction of (-)- $\alpha$-pinene over the Quercus ilex forest, boreal forest and temperate forest.

(i.e. reaction with $\mathrm{OH}$ radical, $\mathrm{O}_{3}$ and $\mathrm{NO}_{3}$ ), and (3) the distribution of the source trees relative to the measurement location and wind direction. Limonene reacts much faster than $\alpha$-pinene and $\beta$-pinene in the free troposphere (Atkinson and Arey, 2003). From the point of view of the chemical composition of the forest air, with more than $70 \%$ of pinene ( $\alpha$-pinene and $\beta$-pinene) and around $30 \%$ of limonene, it appears that the forest is a mixture of Quercus ilex chemotypes with slightly more pinene-dominant chemotype. These findings are also in agreement with the work of Staudt et al. (2001) for the same forest. Being a French forest, we would expect from the screening experiments presented in Sect. 3.1 above, that $(+)-\alpha$-pinene would be the predominant enantiomer. However, the enantiomeric ratio of $\alpha$ pinene in the ambient data does not vary consistently with the previously measured individual identified as French pinene chemotype (chemotype IV).

For comparison, the (-)-enantiomer fraction diel profile over boreal forest and temperate forest are shown in Fig. 9 as well. Chiral monoterpenes were measured over a Scot pine / Spruce forest in the Hyytiälä meteorological station in southern Finland during the summertime of 2010 (Williams et al., 2011; Yassaa et al., 2012). During the 4-week observation above the canopy, in the case of $\alpha$-pinene, the (+)enantiomer was always found to be predominant, while the (-)-enantiomer showed a distinct increase through the day, peaking during the noontime (Fig. 9, boreal forest). From parallel cuvette measurements made on Spruce trees it can be seen that the Spruce trees at the Hyytiälä station emit a strongly (-)-enantiomer-enriched mixture in response to light (Yassaa et al., 2012), possibly explaining the observed variation.

The measurements in the temperate forest located at the mountain Kleiner Feldberg/Taunus, Germany was made during the summer of 2011 (July-August). The enantiomeric profile showed a quite similar trend to that over the boreal forest (Fig. 9). This phenomenon is probably again due to the presence of Spruce trees around the site. 
The initial screening shown in Fig. 3 was performed at $30^{\circ} \mathrm{C}$ and 1000 PAR which corresponds approximately to ambient noontime conditions. In the ambient data (see Fig. 8), it can be seen that throughout the morning, with increasing temperature and light, the $\alpha$-pinene enantiomeric ratio trends from (-)- $\alpha$-pinene enrichment to racemic, that is becomes more enriched in the $(+)-\alpha$-pinene enantiomer. This behaviour is only exhibited by the Spanish pinene chemotype (see Fig. 5). Therefore, we have to conclude that this forest is very likely a mixture of the Spanish pinene chemotype or at least we have one such individual with strong emission rates close to the measurement tower. It appears initially disappointing that the ambient measurements do not correspond more closely to the emissions of the previously measured French chemotypes. Based on the laboratory work shown here, diel variations in enantiomeric ratios could be quite different at different locations in the forest if the French chemotypes predominate elsewhere. However, it must be borne in mind that the natural environment outside the laboratory contains many more stimuli than simply light and temperature and additional sources. The effect of damage by insects may have been an additional driving force on the enantiomeric emissions and significant emissions may have occurred from vegetation (grasses and shrubs) and soil in the understory. Diel cycles in enantiomeric ratios may be influenced by vegetation with a wide footprint and that separate light- and temperature-driven emissions from different species within the ecosystem can likewise cause diel cycles.

\section{Summary and conclusions}

During this laboratory- and field-based study, conducted from 2009 to 2011, enantiomeric monoterpene characterization was investigated as a function of chemotype, light and temperature.

The screening experiments of Quercus ilex emissions under standard conditions, together with the results from the light and temperature responses, indicated that the compositional profile of its emissions is mainly genetically controlled. Furthermore, this limited sample set has provided an interesting hypothesis for regional identification according to enantiomeric chemotype.

Monoterpene emission rates from Quercus ilex were found to be controlled by light and temperature, while Rosmarinus officinalis and Pinus halepensis emitted monoterpene depending mostly on temperature. However, the (-)enantiomer fraction of the main monoterpenes, namely (-)$\alpha$-pinene $\%$ is not strongly affected by light and temperature. The biggest differentiation of the enantiomeric variations were found among individuals from the same species, for instance one Quercus ilex showed a clear (-)- $\alpha$-pinene predominance, while another one was found to have an enantiomeric excess of $(+)-\alpha$-pinene. This suggests that the enantiomeric composition is inherent for a given individual and that several enantiomeric chemotypes exist within a given plant species. These enantiomeric variations have little impact on the overall emission of the monoterpenes which respond to temperature and light according to the existing algorithms reasonably well.

There is no significant evidence for an enantiomeric trend as a function of temperature or light in the leaf emission that can be related to a leaf-scale process. Yet interestingly, field data has repeatedly shown smoothly varying enantiomeric ratios throughout the diel cycle, even for a campaign in which incident wind directions (and hence fetch) has varied significantly. Based on the laboratory experiments, it seems that at different points in the forest the diel cycle in the enantiomeric ratios should be different, dependent on the local distribution of chemotypes. Yet, despite multiple changes in wind speed and direction experiences in these longer-term boreal/temperate campaigns, the enantiomeric ratio cycle remains present and consistent. Several clear enantiomeric ratio diel cycles have been reported over different ecosystems, including a Mediterranean stone pine forest (Song et al., 2011), an oak forest (this study) and a boreal forest (Yassaa et al., 2012). While the forests in Spain and Finland both show an enrichment of $(-)-\alpha$-pinene at noontime (Song et al., 2011; Yassaa et al., 2012), in France the opposite was observed.

In the future, temperature is predicted to increase. From the research presented above it can be seen that the overall enantiomeric signature of the existing forest will change only weakly as a consequence. Only if evolutionary pressure is exerted on a particular chemotype is the overall signal likely to change. Such enantiomeric effects may seem subtle, however, for insects and birds that use olfactory signals for their everyday life such changes may have important consequences.

Acknowledgements. The authors greatly acknowledge the assistance and laboratory support by Jean-Marc Ourcival, Bruno Buatois and David Degueldre (UMR 5175 CEFE, Campus CNRS). We thank Araceli Bracho Nunez for assistance with sampling and generating the schematic of the dynamic leaf chamber.

The service charges for this open access publication have been covered by the Max Planck Society.

Edited by: X. Wang

\section{References}

Arneth, A. and Niinemets, U.: Induced BVOCs: how to bug our models?, Trend Plant. Sci., 15, 118-125, 2010.

Arneth, A., Niinemets, Ü., Pressley, S., Bäck, J., Hari, P., Karl, T., Noe, S., Prentice, I. C., Serça, D., Hickler, T., Wolf, A., and Smith, B.: Process-based estimates of terrestrial ecosystem isoprene emissions: incorporating the effects of a di- 
rect $\mathrm{CO}_{2}$-isoprene interaction, Atmos. Chem. Phys., 7, 31-53, doi:10.5194/acp-7-31-2007, 2007.

Arneth, A., Monson, R. K., Schurgers, G., Niinemets, Ü., and Palmer, P. I.: Why are estimates of global terrestrial isoprene emissions so similar (and why is this not so for monoterpenes)?, Atmos. Chem. Phys., 8, 4605-4620, doi:10.5194/acp-8-46052008, 2008 .

Atkinson, R. and Arey, J.: Gas-phase tropospheric chemistry of biogenic volatile organic compounds: a review, Atmos. Environ., 37, S197-S219, 2003.

Baldwin, I. T., Halitschke, R., Paschold, A., von Dahl, C. C., and Preston, C. A.: Volatile signaling in plant-plant interactions: "Talking trees" in the genomics era, Science, 311, 812-815, doi:10.1126/science.1118446, 2006.

Bertin, N., Staudt, M., Hansen, U., Seufert, G., Ciccioli, P., Foster, P., Fugit, J. L., and Torres, L.: Diurnal and seasonal course of monoterpene emissions from Quercus ilex (L.) under natural conditions - Applications of light and temperature algorithms, Atmos. Environ., 31, 135-144, doi:10.1016/s13522310(97)00080-0, 1997.

Blanch, J. S., Penuelas, J., and Llusia, J.: Sensitivity of terpene emissions to drought and fertilization in terpene-storing Pinus halepensis and non-storing Quercus ilex, Physiol. Plantarum, 131, 211-225, doi:10.1111/j.1399-3054.2007.00944.x, 2007.

Bracho-Nunez, A., Welter, S., Staudt, M., and Kesselmeier, J.: Plant-specific volatile organic compound emission rates from young and mature leaves of Mediterranean vegetation, J. Geophys. Res.-Atmos., 116, D16304, doi:10.1029/2010jd015521, 2011.

Curci, G., Beekmann, M., Vautard, R., Smiatek, G., Steinbrecher, R., Theloke, J., and Friedrich, R.: Modelling study of the impact of isoprene and terpene biogenic emissions on European ozone levels, Atmos. Environ., 43, 1444-1455, doi:10.1016/j.atmosenv.2008.02.070, 2009.

Degenhardt, J. and Gershenzon, J.: Demonstration and characterization of (E)-nerolidol synthase from maize: a herbivoreinducible terpene synthase participating in (3E)-4,8-dimethyl1,3,7-nonatriene biosynthesis, Planta, 210, 815-822, 2000.

Ebben, C. J., Zorn, S. R., Lee, S. B., Artaxo, P., Martin, S. T., and Geiger, F. M.: Stereochemical transfer to atmospheric aerosol particles accompanying the oxidation of biogenic volatile organic compounds, Geophys. Res. Lett., 38, L16807, doi:10.1029/2011gl048599, 2011.

Eerdekens, G., Yassaa, N., Sinha, V., Aalto, P. P., Aufmhoff, H., Arnold, F., Fiedler, V., Kulmala, M., and Williams, J.: VOC measurements within a boreal forest during spring 2005: on the occurrence of elevated monoterpene concentrations during night time intense particle concentration events, Atmos. Chem. Phys., 9, 8331-8350, doi:10.5194/acp-9-8331-2009, 2009.

Faldt, J., Solheim, H., Langstrom, B., and Borg-Karlson, A. K.: Influence of fungal infection and wounding on contents and enantiomeric compositions of monoterpenes in phloem of Pinus sylvestris, J. Chem. Ecol., 32, 1779-1795, doi:10.1007/s10886006-9109-9, 2006.

Fischbach, R. J., Staudt, M., Zimmer, I., Rambal, S., and Schnitzler, J. P.: Seasonal pattern of monoterpene synthase activities in leaves of the evergreen tree Quercus ilex, Physiol. Plantarum, 114, 354-360, 2002.
Fuentes, J. D., Lerdau, M., Atkinson, R., Baldocchi, D., Bottenheim, J. W., Ciccioli, P., Lamb, B., Geron, C., Gu, L., Guenther, A., Sharkey, T. D., and Stockwell, W.: Biogenic hydrocarbons in the atmospheric boundary layer: A review, B. Am. Meteorol. Soc., 81, 1537-1575, 2000.

Gershenzon, J. and Dudareva, N.: The function of terpene natural products in the natural world, Nature Chemical Biology, 3, 408414, doi:10.1038/nchembio.2007.5, 2007.

Ghirardo, A., Koch, K., Taipale, R., Zimmer, I., Schnitzler, J. P., and Rinne, J.: Determination of de novo and pool emissions of terpenes from four common boreal/alpine trees by ${ }^{13} \mathrm{CO}_{2}$ labelling and PTR-MS analysis, Plant Cell Environ., 33, 781-792, doi:10.1111/j.1365-3040.2009.02104.x, 2010.

Grote, R. and Niinemets, U.: Modeling volatile isoprenoid emissions - a story with split ends, Plant Biol., 10, 8-28, 2008.

Grote, R., Keenan, T., Lavoir, A. V., and Staudt, M.: Processbased simulation of seasonality and drought stress in monoterpene emission models, Biogeosciences, 7, 257-274, 2010, http://www.biogeosciences.net/7/257/2010/.

Guenther, A.: The contribution of reactive carbon emissions from vegetation to the carbon balance of terrestrial ecosystems, Chemosphere, 49, 837-844, doi:10.1016/S00456535(02)00384-3, 2002.

Guenther, A. B., Zimmerman, P. R., Harley, P. C., Monson, R. K., and Fall, R.: Isoprene and Monoterpene Emission Rate Variability - Model Evaluations and Sensitivity Analyses, J. Geophys. Res.-Atmos., 98, 12609-12617, 1993.

Guenther, A., Hewitt, C. N., Erickson, D., Fall, R., Geron, C., Graedel, T., Harley, P., Klinger, L., Lerdau, M., Mckay, W. A., Pierce, T., Scholes, B., Steinbrecher, R., Tallamraju, R., Taylor, J., and Zimmerman, P.: A Global-Model of Natural Volatile Organic-Compound Emissions, J. Geophys. Res.-Atmos., 100, 8873-8892, 1995.

Guenther, A., Karl, T., Harley, P., Wiedinmyer, C., Palmer, P. I., and Geron, C.: Estimates of global terrestrial isoprene emissions using MEGAN (Model of Emissions of Gases and Aerosols from Nature), Atmos. Chem. Phys., 6, 3181-3210, doi:10.5194/acp-63181-2006, 2006.

Hopke, J., Donath, J., Blechert, S., and Boland, W.: HerbivoreInduced Volatiles - the Emission of Acyclic Homoterpenes from Leaves of Phaseolus-Lunatus and Zea-Mays Can Be Triggered by a Beta-Glucosidase and Jasmonic Acid, Febs Letters, 352, 146-150, 1994.

Keenan, T., Niinemets, U., Sabate, S., Gracia, C., and Penuelas, J.: Seasonality of monoterpene emission potentials in Quercus ilex and Pinus pinea: Implications for regional VOC emissions modeling, J. Geophys. Res.-Atmos., 114, D22202, doi:10.1029/2009jd011904, 2009.

Kesselmeier, J. and Staudt, M.: Biogenic volatile organic compounds (VOC): An overview on emission, physiology and ecology, J. Atmos. Chem., 33, 23-88, 1999.

Loreto, F. and Schnitzler, J. P.: Abiotic stresses and induced BVOCs, Trends Plant Sci., 15, 154-166, doi:10.1016/j.tplants.2009.12.006, 2010.

Loreto, F. and Velikova, V.: Isoprene produced by leaves protects the photosynthetic apparatus against ozone damage, quenches ozone products, and reduces lipid peroxidation of cellular membranes, Plant Physiol., 127, 1781-1787, doi:10.1104/Pp.010497, 2001. 
Loreto, F., Ciccioli, P., Brancaleoni, E., Cecinato, A., Frattoni, M., and Sharkey, T. D.: Different sources of reduced carbon contribute to form three classes of terpenoid emitted by Quercus ilex L leaves, P. Natl. Acad. Sci. USA, 93, 9966-9969, 1996a.

Loreto, F., Ciccioli, P., Cecinato, A., Brancaleoni, E., Frattoni, M., Fabozzi, C., and Tricoli, D.: Evidence of the photosynthetic origin of monoterpenes emitted by Quercus ilex L leaves by C-13 labeling, Plant Physiol., 110, 1317-1322, 1996b.

Loreto, F., Bagnoli, F., and Fineschi, S.: One species, many terpenes: matching chemical and biological diversity, Trends Plant Sci., 14, 416-420, doi:10.1016/j.tplants.2009.06.003, 2009.

Mahmoud, S. S. and Croteau, R. B.: Strategies for transgenic manipulation of monoterpene biosynthesis in plants, Trends Plant Sci., 7, 366-373, 2002.

Martin, D. M., Faldt, J., and Bohlmann, J.: Functional characterization of nine Norway spruce TPS genes and evolution of gymnosperm terpene synthases of the TPS-d subfamily, Plant Physiol., 135, 1908-1927, doi:10.1104/pp.104.042028, 2004.

McKinney, K. A., Lee, B. H., Vasta, A., Pho, T. V., and Munger, J. $\mathrm{W}$.: Emissions of isoprenoids and oxygenated biogenic volatile organic compounds from a New England mixed forest, Atmos. Chem. Phys., 11, 4807-4831, doi:10.5194/acp-11-4807-2011, 2011.

Monson, R. K., Grote, R., Niinemets, U., and Schnitzler, J. P.: Modeling the isoprene emission rate from leaves, New Phytol., 195, 541-559, doi:10.1111/j.1469-8137.2012.04204.x, 2012.

Niinemets, U., Seufert, G., Steinbrecher, R., and Tenhunen, J. D.: A model coupling foliar monoterpene emissions to leaf photosynthetic characteristics in Mediterranean evergreen Quercus species, New Phytol., 153, 257-275, 2002.

Niinemets, Ü., Kuhn, U., Harley, P. C., Staudt, M., Arneth, A., Cescatti, A., Ciccioli, P., Copolovici, L., Geron, C., Guenther, A., Kesselmeier, J., Lerdau, M. T., Monson, R. K., and Peñuelas, J.: Estimations of isoprenoid emission capacity from enclosure studies: measurements, data processing, quality and standardized measurement protocols, Biogeosciences, 8, 2209-2246, doi:10.5194/bg-8-2209-2011, 2011.

Noziere, B., Gonzalez, N. J. D., Borg-Karlson, A. K., Pei, Y. X., Redeby, J. P., Krejci, R., Dommen, J., Prevot, A. S. H., and Anthonsen, T.: Atmospheric chemistry in stereo: A new look at secondary organic aerosols from isoprene, Geophys. Res. Lett., 38, L11807, doi:10.1029/2011g1047323, 2011.

Penuelas, J. and Staudt, M.: BVOCs and global change, Trends Plant Sci., 15, 133-144, doi:10.1016/j.tplants.2009.12.005, 2010.

Phillips, M. A., Savage, T. J., and Croteau, R.: Monoterpene synthases of loblolly pine (Pinus taeda) produce pinene isomers and enantiomers, Arch. Biochem. Biophys., 372, 197-204, 1999.

Piccot, S. D., Watson, J. J., and Jones, J. W.: A Global Inventory of Volatile Organic-Compound Emissions from Anthropogenic Sources, J. Geophys. Res.-Atmos., 97, 9897-9912, 1992.

Plaza, J., Nunez, L., Pujadas, M., Perrez-Pastor, R., Bermejo, V., Garcia-Alonso, S., and Elvira, S.: Field monoterpene emission of Mediterranean oak (Quercus ilex) in the central Iberian Peninsula measured by enclosure and micrometeorological techniques: Observation of drought stress effect, J. Geophys. Res.-Atmos., 110, D01105, doi:10.1029/2004jd005168, 2005.

Rostelien, T., Stranden, M., Borg-Karlson, A. K., and Mustaparta, H.: Olfactory receptor neurons in two heliothine moth species responding selectively to aliphatic green leaf volatiles, aromatic compounds, monoterpenes and sesquiterpenes of plant origin, Chem. Senses, 30, 443-461, doi:10.1093/chemse/bji039, 2005.

Schurgers, G., Arneth, A., Holzinger, R., and Goldstein, A. H.: Process-based modelling of biogenic monoterpene emissions combining production and release from storage, Atmos. Chem. Phys., 9, 3409-3423, doi:10.5194/acp-9-3409-2009, 2009.

Sharkey, T. D. and Singsaas, E. L.: Why Plants Emit Isoprene, Nature, 374, 769-769, doi:10.1038/374769a0, 1995.

Song, W., Williams, J., Yassaa, N., Martinez, M., Carnero, J. A. A., Hidalgo, P. J., Bozem, H., and Lelieveld, J.: Winter and summer characterization of biogenic enantiomeric monoterpenes and anthropogenic BTEX compounds at a Mediterranean Stone Pine forest site, J. Atmos. Chem., 68, 233-250, doi:10.1007/s10874012-9219-4, 2011.

Staudt, M. and Bertin, N.: Light and temperature dependence of the emission of cyclic and acyclic monoterpenes from holm oak (Quercus ilex L.) leaves, Plant Cell Environ., 21, 385-395, 1998.

Staudt, M. and Lhoutellier, L.: Monoterpene and sesquiterpene emissions from Quercus coccifera exhibit interacting responses to light and temperature, Biogeosciences, 8, 2757-2771, doi:10.5194/bg-8-2757-2011, 2011.

Staudt, M. and Seufert, G.: Light-Dependent Emission of Monoterpenes by Holm Oak (Quercus-Ilex L), Naturwissenschaften, 82, 89-92, 1995.

Staudt, M., Bertin, N., Frenzel, B., and Seufert, G.: Seasonal variation in amount and composition of monoterpenes emitted by young Pinus pinea trees - Implications for emission modeling, J Atmos. Chem., 35, 77-99, 2000.

Staudt, M., Mandl, N., Joffre, R., and Rambal, S.: Intraspecific variability of monoterpene composition emitted by Quercus ilex leaves, Can. J. Forest Res., 31, 174-180, 2001.

Staudt, M., Rambal, S., Joffre, R., and Kesselmeier, J.: Impact of drought on seasonal monoterpene emissions from Quercus ilex in southern France, J. Geophys. Res.-Atmos., 107, 4602, doi:10.1029/2001jd002043, 2002.

Staudt, M., Joffre, R., and Rambal, S.: How growth conditions affect the capacity of Quercus ilex leaves to emit monoterpenes, New Phytol., 158, 61-73, doi:10.1046/j.14698137.2003.00722.x, 2003.

Staudt, M., Mir, C., Joffre, R., Rambal, S., Bonin, A., Landais, D., and Lumaret, R.: Isoprenoid emissions of Quercus spp. (Q-suber and Q-ilex) in mixed stands contrasting in interspecific genetic introgression, New Phytol., 163, 573-584, doi:10.1111/j.14698137.2004.01140.x, 2004.

Stokes, G. Y., Chen, E. H., Buchbinder, A. M., Paxton, W. F., Keeley, A., and Geiger, F. M.: Atmospheric Heterogeneous Stereochemistry, J. Am. Chem. Soc., 131, 13733-13737, doi:10.1021/Ja904206t, 2009.

Tooker, J. F. and Hanks, L. M.: Stereochemistry of host plant monoterpenes as mate location cues for the gall wasp Antistrophus rufus, J. Chem. Ecol., 30, 473-477, 2004.

van Dam, N. M., Qiu, B. L., Hordijk, C. A., Vet, L. E. M., and Jansen, J. J.: Identification of Biologically Relevant Compounds in Aboveground and Belowground Induced Volatile Blends, J. Chem. Ecol., 36, 1006-1016, doi:10.1007/s10886-010-9844-9, 2010. 
Williams, J., Yassaa, N., Bartenbach, S., and Lelieveld, J.: Mirror image hydrocarbons from Tropical and Boreal forests, Atmos. Chem. Phys., 7, 973-980, doi:10.5194/acp-7-973-2007, 2007.

Williams, J., Crowley, J., Fischer, H., Harder, H., Martinez, M., Petäjä, T., Rinne, J., Bäck, J., Boy, M., Dal Maso, M., Hakala, J., Kajos, M., Keronen, P., Rantala, P., Aalto, J., Aaltonen, H., Paatero, J., Vesala, T., Hakola, H., Levula, J., Pohja, T., Herrmann, F., Auld, J., Mesarchaki, E., Song, W., Yassaa, N., Nölscher, A., Johnson, A. M., Custer, T., Sinha, V., Thieser, J., Pouvesle, N., Taraborrelli, D., Tang, M. J., Bozem, H., Hosaynali-Beygi, Z., Axinte, R., Oswald, R., Novelli, A., Kubistin, D., Hens, K., Javed, U., Trawny, K., Breitenberger, C., Hidalgo, P. J., Ebben, C. J., Geiger, F. M., Corrigan, A. L., Russell, L. M., Ouwersloot, H. G., Vilà-Guerau de Arellano, J., Ganzeveld, L., Vogel, A., Beck, M., Bayerle, A., Kampf, C. J., Bertelmann, M., Köllner, F., Hoffmann, T., Valverde, J., González, D., Riekkola, M.-L., Kulmala, M., and Lelieveld, J.: The summertime Boreal forest field measurement intensive (HUMPPA-COPEC-2010): an overview of meteorological and chemical influences, Atmos. Chem. Phys., 11, 10599-10618, doi:10.5194/acp-11-10599-2011, 2011.

Yassaa, N. and Williams, J.: Analysis of enantiomeric and nonenantiomeric monoterpenes in plant emissions using portable dynamic air sampling/solid-phase microextraction (PDAS-SPME) and chiral gas chromatography/mass spectrometry, Atmos. Environ., 39, 4875-4884, 2005.
Yassaa, N. and Williams, J.: Enantiomeric monoterpene emissions from natural and damaged Scots pine in a boreal coniferous forest measured using solid-phase microextraction and gas chromatography/mass spectrometry, J. Chromatogr. A, 1141, 138144, doi:10.1016/j.chroma.2006.12.006, 2007.

Yassaa, N., Meklati, B. Y., and Cecinato, A.: Evaluation of monoterpenic biogenic volatile organic compounds in ambient air around Eucalyptus globulus, Pinus halepensis and Cedrus atlantica trees growing in Algiers city area by chiral and achiral capillary gas chromatography, Atmos. Environ., 34, 2809-2816, 2000.

Yassaa, N., Peeken, I., Zollner, E., Bluhm, K., Arnold, S., Spracklen, D., and Williams, J.: Evidence for marine production of monoterpenes, Environ. Chem., 5, 391-401, doi:10.1071/En08047, 2008.

Yassaa, N., Song, W., Lelieveld, J., Vanhatalo, A., Bäck, J., and Williams, J.: Diel cycles of isoprenoids in the emissions of Norway spruce, four Scots pine chemotypes, and in Boreal forest ambient air during HUMPPA-COPEC-2010, Atmos. Chem. Phys., 12, 7215-7229, doi:10.5194/acp-12-7215-2012, 2012.

Zimmer, W., Bruggemann, N., Emeis, S., Giersch, C., Lehning, A., Steinbrecher, R., and Schnitzler, J. P.: Process-based modelling of isoprene emission by oak leaves, Plant Cell Environ., 23, 585595, 2000. 